Yalçın, H., Erkoç, E. ve Yılmaz, Y. (2020). Evaluations of Home-Educated Students and Their Families on the Education Process.

\title{
EVALUATIONS OF HOME-EDUCATED STUDENTS AND THEIR FAMILIES ON THE EDUCATION PROCESS
}

\author{
https://doi.org/10.35344/japss.558362 Hatice YALÇIN ${ }^{1}$, Emine ERKOC², Yağmur YILMAZ ${ }^{3}$
}

\begin{abstract}
Due to various health problems, the students who cannot attend schools are educated at home but there are not enough studies available on this subject. Thus, the aim of this study was to evaluate perceptions of the students who are ducated at hopme due to the their chronic sickness and their families about their home education processes. The qualitative research method was implemented as a case study including semi-structured interview technique. The research group of the study was home-educated students $(n=46)$ and their families $(n=46)$. After the data collection process was completed, the data were evaluated using descriptive analysis by stating as frequencies and percentages. $78,2 \%$ of the parents in the research group expressed that their children benefited from home education services, as they were located in a safe environment. All of the parents were found to be concerned that their social development was insufficient. $89,1 \%$ of them were generally satisfied with home education practices. $78,2 \%$ of the families stated that teachers should have been available from all subjects, $63 \%$ of them said that the educational materials were inadequate, and $60 \%$ of them pointed out that the course books used within education should have been more visual and enjoyable. $86.9 \%$ of these children stated that after the home education practice, there was a decrease in some their symptoms such as anger, depression, frustration and insomnia.
\end{abstract}

Keywords: Home education, children with special needs, families with children with chronic sickness, education process, case study

\section{Introduction}

\subsection{Introduce the Problem}

Although education is a right for all individuals, some individuals cannot benefit from this right. This is mostly due to such individuals' special handicap situations (Morton, 2010). Required by the principle of equal opportunity and chances in education, special education is referred to as comprising all of the educational services that aim to address to the children with special needs,

1 Asst. Prof.Dr. KTO Karatay University. School of Health Sciences. Department of Child Development. hatice.yalcin@karatay.edu.tr, ORCID ID: https://orcid.org/ 0000-0003-0237-2978

2 Student. KTO Karatay University. Department of Family Counselling. mine-erkoc@hotmail.com, ORCID ID: https://orcid.org/0000-0001-9800-9377

3 Student. KTO Karatay University. Department of Family Counselling. yagmur.yilmaz@gmail.com, ORCID ID: https://orcid.org/ 0000-0002-7629-950X 
which are different from those of normal development, as well as intending to increase the capacity of gifted individuals to the top of their potentials; it also consists of educational services, which are individually planned and provided to students, who differ significantly from a student with average characteristics, and seeking to maximize the possibility of an individual who is supposed to live independently (Taylor et all, 2011). Therefore, the education in childhood should be suitable to the needs and features of children and be given as early as possible, which is a must not only for children and their parents but also the society they live in (Vandenbroeck, Roets \& Roose, 2012).

As regards the students who cannot attend school due to various health problems, an article, issued on January 25, 2006 (amended later on the issue 2629, dated on February 2017), was published on 'Directives by the Ministry of National Education for the Individuals Needing Special Education at Home' and as of these directives, such education activities have been provided by the Turkish Government in Turkey.

Special education activities are carried out in two ways: Institution based and home based. Home-based special education activities are the ones aiming to provide education within the most natural environments of individuals with special needs and encouraging the highest level of participation by the family members in the educational activities. Home-based special education activities offer the most suitable environment for determining the needs of the family in their natural habitats, incorporating family members into the planning process, as well as meeting the needs of the individual with special needs in a natural living environment (Birkan, 2002). Families and childhood education services act as an important sphere for living and learning healthy eating behaviour in early life (Vandenbroeck, Roets \& Roose, 2012).

With regard to the Direction of Home and Hospital Education Services (The Ministry of National Education, 2010), home education is defined as a training based on the principle of providing education services at home to those who do not directly benefit from formal education maintained either by pre-school, primary and secondary education or special education institutions because of health problems of some individuals who need special education. According to this direction, official authorities are expected to designate whether an individual can benefit directly from the formal education institution by evaluating the physical, social and economic aspects. The planning, implementation and monitoring of training services are carried out without considering any limited period of time; thus home education service is designated by the relevant board of education, while education service at hospitals is determined by consulting the opinions of families and a physician involved.

Home education service is provided by a visiting teacher of special education; whereas hospital education service has to be administered by a class teacher or a teacher of any subjects. However, within the home education service, teachers of other subjects can also be assigned to work considering the age, developmental characteristics and primary needs of the relevant person. The person maintains his/her education according to the education program of the school where $\mathrm{s} / \mathrm{he}$ is registered; and an Individualized Education Program- IEP is prepared in accordance with his/her 
training needs. During home education either at home or at the hospital, the family is informed, supported and integrated in all stages of the process. The health status, development and competencies of the home-educated individual are evaluated continuously, as well as the revisions and arrangements that are made accordingly (The Ministry of National Education, 2017). In addition, home-schooling or education is the most rigorous practice that requires active participation of family members in educational activities (Smith \& Williams, 2009). Home education practice is actively carried out in the western states of Canada, such as Alberta and British Columbia. The number of students involved in the home education process in primary school is higher than in secondary school (Davies, 2008, 1998: 8; Taylor, 2012). Home education practice has emerged as a necessity in a limited number of schools in the United States and become widespread considerably in the USA, Canada, England, Germany, Belgium, France and Denmark (Basham, Merrifield \& Hepburn, 2007; Cooper \& Sureau, 2007; Green \& Hoover-Dempsey, 2007; Memduhoglu et all, 2015).

\subsection{Explore Importance of the Problem}

The number of research on home education is limited in Turkey. The practice of home education is actively practiced in almost every province but student and family members' opinions do not seem to have been adequately addressed and revealed. Therefore, the opinions and suggestions of those involved in such a training process should be evaluated in details so that more qualified home education practices can be implemented accordingly. It is important for the quality education of children with special needs to bring the studies related to the home education practice into the literature. Therefore, this research is of importance in terms of meeting the basic educational needs of handicapped people and establishing an infrastructure to demonstrate the degree to which home education is provided for children with handicaps. Within this scope, the aim of this executed study is to obtain data about home education practice, which has been implemented since 2010 in Turkey; and to demonstrate how it is actually carried out in practice, alongside with its positive and difficult aspects. Thus, the layout of the research seeked to evaluate the perspectives of these children and their family members in the educational practices, investigate the relationship between the socio-demographic characteristics and the perceptions about home education, which will hopefully provide data for the initiative programs to be established and lead to the studies to be conducted in this field. Furthermore, it will be possible to reveal the literature about the concept of home education; to construct new studies as regards with this field and to avert inadequate practices accordingly.

\subsection{State Hypotheses and Their Correspondence to Research Design}

The aim of this study was to evaluate the perceptions of students and their family members about their home education process. The researcher tried to find the answers to the following research questions: 
1. What are the effects of home education on a child's cognitive, affective, linguistic or social development?

2. What are the expectations and suggestions of family members about the education at home

3. What are the contributions of the child development field to home education practices?

\section{Method}

\subsection{Identify Subsections}

This study was carried out using a semi-structured interview technique, which is one of the qualitative research methods. Qualitative research uses qualitative data collection instruments such as interview forms; thus it follows up a qualitative process to present perceptions and phenomena from realistic and holistic perspectives. In addition, a semi structured interview method can be defined as the way the researcher investigates the feelings, emotions, beliefs and thoughts of people in depth. (Yildirim \& Şimşek, 2008, 108). However, maximum variation sampling was used in the study. The purpose of selecting such sampling system was to reflect the variation of the research group in the maximum level by creating a relatively small sample in the maximum variation sampling. With such a design in the under-researched situation, different characteristics of the students and families were taken into consideration (Roussinov, Zhao, 2003). Since there were the limited number of students who could not attend school and received education services at home, the researcher had to carry out the research with few students, thus, in this study the researcher used typical case sampling, which was one of purposive sampling methods (Patton, 2002; Şahin, Balta, Ercan, 2010). Then, the researcher investigated the perceptions of students and their families about their home education process they were involved in.

\subsection{Participant (Subject) Characteristics}

The students getting home education in Konya and their families made up the population of this study. A total of 46 children and their families $(\mathrm{N}=92)$, who were served by the Counseling and Research Centre (RAM) for Home Education province, constituted the sample research group. The demographic data of the research group are presented in Table 1. 
Table 1: Socio-Demographic Attributes of the Children in the Research Group

\begin{tabular}{|c|c|c|c|}
\hline \multirow[b]{2}{*}{ Attribute } & & \multicolumn{2}{|c|}{ Child } \\
\hline & & $\mathbf{n}$ & $\%$ \\
\hline \multirow[t]{3}{*}{ Age } & $3-6$ & 2 & 4,3 \\
\hline & $6-12$ & 19 & 41,3 \\
\hline & $12-18$ & 25 & 54,3 \\
\hline \multirow[t]{2}{*}{ Gender } & Female & 21 & 45,6 \\
\hline & Male & 25 & 54,3 \\
\hline \multirow[t]{3}{*}{ Number of Siblings } & Only child & 7 & 15,2 \\
\hline & 2-3 siblings & 28 & 60,8 \\
\hline & 4+ siblings & 11 & 23,9 \\
\hline
\end{tabular}

$54.3 \%$ of children in the research group were made up of $12-18$ ages, $41.3 \%$ them are in the 6-12 age group and $4.3 \%$ of them were 3-6 years old. Table 2 shows the handicapping conditions of participating children which brought about them to receive education at home.

Table 2: Disability Status of Children in the Research Group $(\mathrm{N}=46)$

\begin{tabular}{lcc}
\hline Handicap Conditions & $\mathbf{n}$ & $\mathbf{\%}$ \\
\hline Mild intellectual disabilities or physical handicapped & 8 & 17,3 \\
\hline Moderate level of mental or physical handicapped & 11 & 23,9 \\
\hline Severe mental or physical handicapped & 2 & 4,3 \\
\hline Physical handicapped & 9 & 19,5 \\
\hline Hearing impairment & 5 & 10,8 \\
\hline Autism spectrum disorders & 4 & 8,6 \\
\hline Chronic sickness & 7 & 15,2 \\
\hline
\end{tabular}

$23.9 \%$ of children in the research group suffer from mild mental deficiencies or physical handicaps, $19.5 \%$ of them have solely physical handicaps, $17.3 \%$ of them are with mild mental or physical handicaps, $15.2 \%$ have chronic sickness, $8.6 \%$ have autism spectrum disorders (OSD), whereas $4 \%$ have severe mental or physical handicaps. The socio-demographic attributes of the families included in the research group were given in Table 3. 
Table 3: Socio-Demographic Attributes of Parents in the Research Group

\begin{tabular}{llllll}
\hline \multirow{2}{*}{ Attribute } & & \multicolumn{2}{c}{ Mother $(\mathbf{n}=\mathbf{3 5})$} & \multicolumn{2}{c}{ Father $(\mathbf{n}=\mathbf{1 1})$} \\
& & $\mathbf{n}$ & $\mathbf{\%}$ & $\mathbf{n}$ & \% \\
\hline \multirow{3}{*}{ Age } & Under 30 & 7 & 20 & - & - \\
\cline { 2 - 6 } & $31-40$ & 15 & 42,8 & 6 & 54,5 \\
\cline { 2 - 6 } & $41+$ & 13 & 37,1 & 5 & 45,4 \\
\hline \multirow{2}{*}{$\begin{array}{l}\text { Educational } \\
\text { Status }\end{array}$} & Primary School & 20 & 57,1 & - & \\
\cline { 2 - 6 } & Secondary School & 7 & 20 & 3 & 27,2 \\
& High School & 5 & 14,2 & 5 & 45,4 \\
\cline { 2 - 6 } & University Degree & 3 & 8,5 & 3 & 27,2 \\
\hline
\end{tabular}

Of the 46 parents interviewed, 35 of them are mothers (76\%) and 11 of them are fathers $(23.9 \%)$. Among the mothers involved, $42.8 \%$ are between $31-40$ years, $37.1 \%$ are older than 41 , and $20 \%$ of them are under $30.54 .5 \%$ of fathers are between $31-40$ years old and $45.4 \%$ are older than the age of 41 . In addition, $7.1 \%$ of the mothers are the graduates of primary schools, $20 \%$ of them are secondary school graduates, $14.2 \%$ are high school graduates, and $8.5 \%$ have university degrees. Among the fathers interviewed, $45.4 \%$ are high school graduates, $27.2 \%$ have university degrees and $27.2 \%$ of them are secondary school graduates.

\subsection{Analysis of Data}

In this study, in which the interview technique was implemented and content analysis was used to analyse the data collected for this study. The data were first coded, the themes were determined, and then the findings were interpreted after the coding process and the themes had been ascertained. The perceptions were classified by considering the similarities of the statements. The relevant data were expressed as frequencies after the digitization process. The findings were interpreted considering the previous studies by comparing their aspects of conformity. In order to ensure the validity, the research process was explained in details from the preparation of the data collection tool to the implementation and analysis phases. Thus, the findings were compared with other studies on the relevant topic in the literature, while the similarities and differences between the findings and the actual situations were analysed accordingly. After the data collection process was completed, the data were assessed using descriptive analysis, and then the revealed data were expressed as frequencies and percentages.

\section{Results}

The data obtained in the study were evaluated in two scopes; for the children and their families at home. 


\section{Findings from the families of Children who are Educated at Home}

There are several reasons for the families who cannot send their children to the school and must prefer their children to get education at home. The families in the research group have stated that they prefer home education for their children because $26.1 \%$ of the participating families have children with physical disabilities, $23.9 \%$ of them have children with intellectual disabilities, $17.3 \%$ believe that school environment has a negative effect on the child's psychology, $13 \%$ of them are of the opinion that the child's special needs can be satisfied at home more comfortably; $10,8 \%$ of them have stated that in addition to academic courses, religious and moral education can be given better in the home environment, and $8,6 \%$ of the participant parents have pointed out that they have actually some concerns about the negative situations in the school environment.

In the research group, the opinions of parents on positive aspects of home education are given in Table 4.

Table 4. Parents' Opinions on the Positive Aspects of Home Education Practices

\begin{tabular}{lll}
\hline \hline Families' perceptions on the benefits of home education & $n^{*}$ & $\%$
\end{tabular}

\begin{tabular}{llc}
\hline \hline A safer physical learning environment is provided & 36 & 78,2 \\
\hline $\begin{array}{l}\text { The child's health, social, emotional or psychological development is more } \\
\text { comfortable at home }\end{array}$ & 31 & 67,3 \\
\hline $\begin{array}{l}\text { Home education is efficient, as the child's nutrition requirements can be } \\
\text { provided }\end{array}$ & 31 & 67,3 \\
\hline Higher academic performance is achieved thanks to one-to-one instruction & 30 & 65,2 \\
\hline The children can be protected from negative peer influences & 28 & 60,8 \\
\hline $\begin{array}{l}\text { The child is not affected by the attitudes of indiscipline and negativity in } \\
\text { schools }\end{array}$ & 27 & 58,6 \\
\hline The whole family benefits from the teacher's knowledge & 27 & 58,6 \\
\hline According to the gender of the child, male or female teachers can be preferred & 27 & 58,6 \\
\hline There is an opportunity to gain some certain values or beliefs & 18 & 39,1 \\
\hline Financial burdens of government or private schools have decreased & 17 & 36,9 \\
\hline Other (chances to develop close parent-child relationship, self-esteem, etc.) & 17 & 36,9 \\
\hline $\begin{array}{l}\text { Doing the teaching at home enables the child and the family to feel valued } \\
\text { and joyful }\end{array}$ & 17 & 36,9 \\
\hline
\end{tabular}

* More than one option was selected

The families in the research group state that their children have benefitted from the current home education services (78.2\%) primarily because they are situated in a safe environment. In addition, they believe that thanks to home education service providers, their child's health, social, emotional, and psychological states will be developed in a better way $(67.3 \%)$; that the 
child will achieve high academic performance (65.2\%), and s/he can be protected from negative friendship circles $(60.8 \%)$; s/he can stay away from indiscipline and negativity in schools $(58.6 \%)$. On the other hand, $39.1 \%$ of the families stress that the children have educational opportunities to develop some good moral values or beliefs at home. Besides avoiding the financial burden of going to school $(36.9 \%)$, they think that they can better manage the familes-children relationship through home education facilities $(36.9 \%)$, or they can develop some personal traits such as self-esteem better at the home environment $(36.9 \%)$.

In Table 5, perceptions of the families in the research group are given on the negative aspects of home education practices.

Table 5: Parents' Opinions on the Negative Aspects of Home Education Practices

\begin{tabular}{lccc}
\hline \hline Perceptions of families on the negative aspects of home education & $\mathbf{n}^{*}$ & $\mathbf{\%}$ \\
\hline \hline Social development of the children's seems to be insufficient & 46 & 100 \\
\hline $\begin{array}{l}\text { As a result of weakness / fatigue related to the disease, the child may lose } \\
\text { his/her interest in education }\end{array}$ & 45 & 97,8 \\
\hline $\begin{array}{l}\text { In the home environment, materials \& tools such as blackboards and a } \\
\text { projectors are inadequate }\end{array}$ & 45 & 97,8 \\
\hline The child may not have a good interaction with the teacher coming home & 31 & 67,3 \\
\hline Teachers coming home may be pedagogically insufficient & 28 & 60,8 \\
\hline Home education hours can disrupt the order in the home environment & 27 & 58,6 \\
\hline Noise at home due to guests visiting the house & 26 & 56,5 \\
\hline It can be difficult for the teacher to get home & 18 & 39,1 \\
\hline Home education is difficult and tiring if both parents are working & 9 & 19,5 \\
\hline & & &
\end{tabular}

All of the interviewed families are concerned that their child's social development is insufficient due to fact that the child cannot have frequent contacts with his/her peers. $97.8 \%$ of the parents have stated that the child may lose interest in education because of his/her sickness, $97.8 \%$ of them have stressed that the course materials are inadequate, $67.3 \%$ of them think that the teacher-child interaction cannot be established well, 58.6\% of the families are of the opinion that sometimes education hours cannot be adjusted according to the order at the home environment, $56.5 \%$ are concerned about the noise, which may hinder the learning process at home, $39.1 \%$ point out that the teachers find it difficult to get to the house, and $19.5 \%$ of the participants are of the opinion that when both families are working, the home education becomes more difficult.

In Table 6, requests and recommendations of the parents for home education practices are given. 
Table 6: Parents' Requests and Recommendations for Home Education

\begin{tabular}{lcc}
\hline \hline Requests and Suggestions for Education at Home & $\mathbf{n}^{*}$ & $\mathbf{\%}$ \\
\hline \hline More teachers from various subjects should be available & 41 & 89,1 \\
\hline $\begin{array}{l}\text { Home-educated children should gather more frequently with others in social } \\
\text { circles }\end{array}$ & 40 & 86,9 \\
\hline Course materials (maps, models, test equipment, etc.) should be provided & 40 & 86,9 \\
\hline A psychological counsellor should come home for support & 36 & 78,2 \\
\hline $\begin{array}{l}\text { Sometimes a group training should be given with the other children having } \\
\text { the same sickness }\end{array}$ & 32 & 69,5 \\
\hline Course hours must be increased & 27 & 58,6 \\
\hline Computer training should be given & 22 & 47,8 \\
\hline Teachers should not switch so often & 22 & 47,8 \\
\hline $\begin{array}{l}\text { Officials should sometimes come home and supervise the educational } \\
\text { activities }\end{array}$ & 18 & 39,1 \\
\hline
\end{tabular}

Recommendations of the families for home education are as follows: $89.1 \%$ of the families suggest involving different teachers, $86.9 \%$ of them demand increasing social activities, $86.9 \%$ of them expect to have various materials at home, $78.2 \%$ of them request an psychological specialist to be available so as to support both themselves and other family members, $69.5 \%$ ask for group education to be given to the children, $58.6 \%$ recommend increasing the course time, $47.8 \%$ of them demand computer training, $47.8 \%$ of the participant families hope the teachers not to be changed so often, and finally $39.1 \%$ of them want to see the official authorities at home to inspect the training practices.

One-to-one interviews were conducted with the participant children who received education at home and the perceptions of children about education were summarized in Table 7. 
Table 7: Opinions of Children's about Education in the Research Group

\begin{tabular}{|c|c|c|c|}
\hline & Children's opinions about the home education & 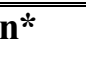 & 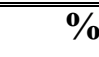 \\
\hline \multirow{7}{*}{$\begin{array}{l}\text { General } \\
\text { perceptions }\end{array}$} & I am happy to have education at home & 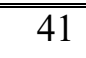 & 89,1 \\
\hline & $\begin{array}{l}\text { Negative feelings of mine such as anger, burst of rage, } \\
\text { depression have decreased }\end{array}$ & 40 & 86,9 \\
\hline & $\begin{array}{l}\text { I have developed my hand muscles / reading skills / math } \\
\text { knowledge etc.. }\end{array}$ & 40 & 86,9 \\
\hline & $\begin{array}{l}\text { Home environment has been more positive as of respect, } \\
\text { gentle conversations and propriety. }\end{array}$ & 32 & 69,5 \\
\hline & $\begin{array}{l}\text { Everyone in the house can talk about their feelings with } \\
\text { the teacher }\end{array}$ & 27 & 58,6 \\
\hline & $\begin{array}{l}\text { Self-confidence development thanks to dealing with us } \\
\text { personally }\end{array}$ & 27 & 58,6 \\
\hline & Even in a little, I feel like I'm involved in social life. & 18 & 39,1 \\
\hline \multirow{6}{*}{$\begin{array}{l}\text { Perceptions } \\
\text { about the } \\
\text { teacher and } \\
\text { training }\end{array}$} & Teachers coming home have brought us happiness & 38 & 82,6 \\
\hline & $\begin{array}{l}\text { When my teacher switches, I feel very bad and I lose my } \\
\text { eagerness to learn }\end{array}$ & 37 & 80,4 \\
\hline & $\begin{array}{l}\text { Teachers are very diligent and enthusiastic, so they can } \\
\text { motivate us well }\end{array}$ & 37 & 80,4 \\
\hline & Teachers from all branches should come home & 36 & 78,2 \\
\hline & $\begin{array}{l}\text { Materials such as maps, projectors and models should } \\
\text { also be brought home }\end{array}$ & 29 & 63 \\
\hline & $\begin{array}{l}\text { It would be better if books were more visual, and most of } \\
\text { the learning were fun }\end{array}$ & 28 & 60 \\
\hline
\end{tabular}

* More than one option was selected

Of all children in the research group, $89.1 \%$ of them are generally satisfied with the home education. $86.9 \%$ the children have pointed out that their psychological situations have got better with the education at home, $86.9 \%$ say to have developed hand muscles as well as some improvement such as reading, $69.5 \%$ state that there have been positive progress in terms of talks with the family members, $58.6 \%$ of the participants express that they have felt valued, $39.1 \%$ of them mention that they have left home and socialized with the teacher in some social activities. In addition, regarding teacher and the curriculum, $82.6 \%$ of the children are of the opinion that the teachers make everyone happy at home, $80.4 \%$ of them are accustomed to the teacher and get very upset when s/he switches, $80.4 \%$ think that teachers are enthusiastic and motivating, $78.2 \%$ demand that teachers from all branches should be available, $63 \%$ of them state that educational materials are inadequate, and $60 \%$ stress that the books used in training should be more visual and enjoyable.

Undergraduate students of the Department of Child Development participated in home education practices as trainees once a week for 14 weeks and the data were collected by these students. Table 8 shows the views of children and parents about the benefits of child development trainees in the home education practices. 
Table 8: Participating Children's Opinions the about the Child Development Trainee Teachers

\begin{tabular}{|c|c|c|c|}
\hline & $\begin{array}{l}\text { Opinions about the contributions of Child Development } \\
\text { Trainees to home education practices }\end{array}$ & n* & 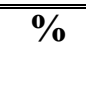 \\
\hline \multirow{7}{*}{$\begin{array}{l}\text { The } \\
\text { perceptions } \\
\text { of students } \\
\text { involved in } \\
\text { home } \\
\text { education }\end{array}$} & They made us play games and we had a lot of fun & 41 & 89,1 \\
\hline & They were like real teachers, but they taught us through games. & 40 & 86,9 \\
\hline & It was very nice to have people smiling at home & 40 & 86,9 \\
\hline & They repeated what the teacher taught, thus I learned better & 38 & 82,6 \\
\hline & $\begin{array}{l}\text { They tried to teach with waste materials in the house, I think } \\
\text { what I learned will be permanent for me }\end{array}$ & 36 & 78,2 \\
\hline & They took care of everyone's problems at home & 30 & 65,2 \\
\hline & They reduced stressing factors, which was quite beneficial & 24 & 52,1 \\
\hline \multirow{6}{*}{$\begin{array}{l}\text { Perceptions } \\
\text { of } \\
\text { Children's, } \\
\text { parents' } \\
\text { about home } \\
\text { education }\end{array}$} & They brought home joy and dynamism & 40 & 86,9 \\
\hline & $\begin{array}{l}\text { They repeated what the teacher taught to my child, which, I } \\
\text { think, will be permanent. }\end{array}$ & 36 & 78,2 \\
\hline & $\begin{array}{l}\text { They dealt not only with my child's psychological problems, but } \\
\text { also with mine. }\end{array}$ & 34 & 73,9 \\
\hline & $\begin{array}{l}\text { They produced games and training materials from simple } \\
\text { supplies at home }\end{array}$ & 22 & 47,8 \\
\hline & $\begin{array}{l}\text { They kept the whole family happy by arranging birthday parties } \\
\text { and little surprises. }\end{array}$ & 22 & 47,8 \\
\hline & $\begin{array}{l}\text { Child development trainees have taught me that there are some } \\
\text { issues I can teach to my own child }\end{array}$ & 18 & 39,1 \\
\hline
\end{tabular}

When asked experts about the child development who came home as trainees for home education practices, $89.1 \%$ of the children in the research group said that they had a lot of fun with them; $86.9 \%$ of children stated that they learned through games; other $86.9 \%$ reflected that they were happy to see some people smiling at home, $82.6 \%$ expressed it was good for them to repeat what they learned, $65.2 \%$ said that the trainee teachers took care of everyone's problems at home, and $52.1 \%$ pointed out that they reduced the sources of stress at the home environment. When asked about their opinions, $86.9 \%$ of the parents stated that the teachers brought home joy, $78.2 \%$ of them said that it was good for their children to revise what they learnt, $73.9 \%$ expressed that teachers dealt with the psychological problems, $47.8 \%$ of the parents mentioned that they learned how to produce games from simple materials at home, $39.1 \%$ of them stated that trainee teachers encouraged self-confidence, which they could think of teaching their own children as well.

\section{Discussion}

In the research group, whereas $57.1 \%$ of the mothers are primary school graduates, $45.4 \%$ of the fathers are high school graduates. The educational background of parents is an important factor for the success of children. In a study carried out in the US by Basham et al. (2007), it was revealed that home-schooled children who had the parents with higher levels of education were 
found to be more successful than those of lower educational backgrounds. The main reasons for the success of the children getting education at home could possibly be due to the factors such as one-to-one trainings and individualized education programs (IEP). When the perceptions of the families are examined, the parents state that home education process is quite necessary and they are very satisfied with the current practices and teachers. Families are generally grateful to the teachers for their efforts. This situation can be explained by the psychological situation in which they are involved in.

The main reason for families to choose home education for their children seems to be the special needs of children. Some families prefer to educate their children in the home environment on account of bad situations in the school environment (poor physical conditions and lack of requirements for the disabled children, oppressive discipline, disrespect for the child, peer bullying etc.). The statistics on this issue actually shows that concerns of families are justifiable. As a problem increasingly getting widespread in schools all over the world and in Turkey, peer bullying is of great importance as it addresses to the 10-19 aged young people, who make up approximately $17 \%$ of Turkey's population according to the data of Turkish Statistics Institute (TurkStat, 2014). In a study, which was conducted by the Ministry of National Education to investigate the cases of violence in the schools, it was revealed that there were the incidents of physical damages that were observed in the $32.8 \%$ of the children, threats and teasing in $19.7 \%$, gossiping and giving silly nicknames in $12.9 \%$, and the damages to possessions / goods in $9.5 \%$. These findings confirm the fact their children are already vulnerable due to their physical and mental disabilities appears to have forced the mothers to provide home education so that they could protect their children from such damages in the school environment.

Regarding home education practices in this study, $78.2 \%$ of families stated that compared to school, a safer physical learning environment was provided at home; and $67.3 \%$ of them expressed that the child's health, social, emotional and psychological developments were more convenient at home. In the interviews, the families pointed out that because of their concerns about the children's special needs; it was not possible for their children to share the same class with the other students at the school. Due to the children's different learning styles, behavioural problems, ongoing care for their illnesses, disability status, physical or mental problems, the families laid emphasis on the fact that child's getting home education built up the sense of security for them. In the studies conducted in the United States regarding the home-schooling practices, it was found that some families thought their children with special needs education could get more suitable training at home according to their learning rates, special interests or learning difficulties (Basham et al., 2007; Brainerd et al., 2002). In her 9-year long-term study on six children with handicaps, Ensign (2000) found that the individualized structure of home-schooling practice provided an opportunity to focus on the necessities of the children in need of special education, such as learning difficulties and giftedness (cited in Taşdan \& Demir, 2010). Altin (2018) revealed that the family members, who looked after individuals with handicaps, were overprotective and treated emotionally in many cases, which inevitably made the disabled individuals rather socially handicapped in the end. 
In this study, $58.6 \%$ of families consider that home education was very useful because of their kids' staying away from the concerns caused by school environment. They expressed their satisfaction with referring to the fact that the child had to receive home education services so as to avoid the concerns such as the security conditions in and outside the school, besides the lack of special education facilities at the school environment. Furthermore, some parents think that education in schools seems to be below the level of training that children are supposed to receive personally. The fact that a home-based educated child has managed to graduate ranking first in a secondary education, moreover some children with physical handicaps have been more successful than their peers in school, prove that the families are relatively justified in their preferences of such education. In a study carried out in some countries as well as Canada and the United States, Basham et al. (2007) report that home-educated children were found to be more successful than their peers studying at school. In a research conducted on 20,000 students in the USA in 1999, it was revealed that the academic achievements of the 1-4 graders educated at home were one year ahead of their peers at school; in addition, the former group gradually outscored the latter as of the 5th grade they were involved in (cited in Hill, 2000). In the relevant studies, it has been consecutively mentioned that children who have continued to practice home-schooling have achieved some positive outcomes in terms of facilitating their learning, choosing the appropriate program, planning, acquiring moral, ethical, cultural and spiritual principles (Smith \& Williams 2009). In Turkey, researcher has not found any distinct statistical data for such school achievements of home-educated children.

In this study, $58.6 \%$ of the families stated that the genders of teachers who were available at their home for education were also important. The majority of the teachers who provided home education services to the target research group were made up of females. This case must have emerged from the demands of parents asking for female teachers. Since the fathers were not available at home during the course hours, the mothers preferred female teachers with the concern that the environment could make some misinterpretations. However, in the cases where a female teacher could not be present at home, the parents cared about the criteria of 'having a close relative, a familiar person or someone from the neighborhood' available at home. Such an attitude of the interviewed families could be best described and referred to the spirit of "piety and closed family type' in the conservative social structure of Konya province.

$36.9 \%$ of the families in this study, stated that they preferred home education with the concern that their children would not be able to fully acquire the basic religious teachings within the school environment, or that educational curricula in schools were contradictory to their own religious beliefs. Marchant and MacDonald found that 45\% of the parents, they researched, opted for home-schooling with their children due to religious matters (cited in Collom, 2005). The demands of families to receive appropriate education on a particular ideological belief have been the primary cause of home education practices from time to time (Green and Hoover-Dempsey, 2007). One of the reasons for families' preferring education at home is to train their children according to the characters and ethics that they desire their kids to have (Bauman, 2001). Therefore, it seems that some families aim to teach their children some certain 
values, beliefs and world views in their home environment. However, in our country, there has been some concerns on the fact that deviating from the general aims of the National Education or the unity of education and leaving the monopoly of education to the family can lead to some consequences such as raising children in line with the aims of various political or ethnic groups, which appears to be undesirable for the official authorities.

There are various opinions about the social development aspect of home education practices. Emphasizing on the fact that school environment is an indispensable socialization environment, some educators claim that home education practices prevent the socialization of the child; the child receiving education at home suffers from social isolation and lack of positive peer effect on learning; moreover his/her cognitive and affective skills remain at low levels (Petrie, 1995; Şad \& Akdağ, 2010). In contrast to this view, Brainerd et al. (2002) report that children who study at home do not have to spend a long time at school, and if the teacher-parent cooperation is well-functioning, the children can go to the library, park trips, and participate in some cultural activities within a comfortable period of time. Thus, it is argued that home-educated children can socialize more than others at school.

When both the mother and the father had to work, the rate of parents, who stated that the home education practices for the child receiving education at home was difficult and even tiring, was found to be $39.1 \%$. Even when the time management of families is appropriate, home education is an application that requires full responsibility (Şad \& Akdağ, 2010). A specific training program must be maintained at home but home education practices are affected by social incidents such as house repairs, visiting guests, birth or death. In California, Home Education Program staffs provide assistance to the parents of children in home-based studies, such as helping them do their homework, designing syllabi and evaluating what the child learns (Cooper \& Sureau, 2007; Hanna, 2011).

In the study, $39.1 \%$ of the families have stated that it is sometimes difficult for the teachers who provide home education to arrive at the child's home from their own houses. The fact that the home-educated children's houses are far away can become a real problem for teachers. Teachers are not provided with services such as a shuttle bus or a free travel card, so they are supposed to cover all of the travel expenses by themselves. In our country, some teachers voluntarily accept the work if the house of the child is close to them but if the house is far away from their location, they do not accept the responsibility. In addition, teachers have to teach the children who are insufficiently developed in cognitive, affective, psycho-motor skills; they also teach handicapped children with sensitive and fragile personalities, therefore, such a teaching practice can be a tiresome process for teachers as they do this in addition to their weekly course loads. In a study on mobile teachers who gave special education service and their problems, Aslan (2015) revealed that the teachers had to wait a long time at bus stops and they had to deal with the difficulties of bad weather conditions.

$97.8 \%$ of the families in the research group reported that child's academic performance decreased very rapidly due to his/her handicap. For the children who suffer different severe diseases such as 
glass bone, myolysis, paralysis, organ transplantation, interruption of education is an expected result. In a study of Aslan (2015), according to the support teachers giving special education, the children, who receive home education, lose interest in learning due to their weakness and fatigue. On the other hand, $97.8 \%$ of the families state that the course materials are insufficient for the home environment and that the inadequacy of the course materials such as blackboard, pictures, maps, projector and computer have posed some problems. These findings are in line with the results of our study. Thus, various findings of research have shown that educational materials have a great role in making educational environments more suitable for students' interests and needs (Sezer, 2017). Academic achievement has also been increased in the classes where the materials are used effectively (Fidan, 2008).

In this study, $58.6 \%$ of the families stated that home education could be disturbed due to noise and such other distracting factors. On account of the fact that there are extended and big families as well as intimate neighbouring relations in the Konya province, the hospitality perception is quite common. During the interviews, the familiess expressed that they had prepared an environment which prevented the noise; and adjusted the traffic of visiting guests.

In a study comparing home-schooling practices applied in the United States, Harman (2012) identified the positive and negative aspects of home education practices. Strengthening family ties, providing a safe environment, having manageable actions and being flexible in the curriculum were referred to as positive aspects; on the other hand the lack of resources, limited opportunities in the socialization of the child, high costs compelling the family and lack of arranged time needed for the child to due to the parent's working lives were described as the negative aspects (cited in Aymen Peker \& Taş, 2017: 144).

Of the children in the research group, $89.1 \%$ were generally satisfied. $86.9 \%$ of the children in the research group stated that symptoms such as anger, burst of rage, depression, shrewishness and insomnia decreased after their home education. However, despite the high rate of psychological recovery, it was observed that the psychological states of children who were studying at home were not as satisfactory as their physiological situations. This outcome can be associated with their being disabled individuals. In general, it seems that teachers and their teaching methods have been welcomed by the children, they also say that they have benefitted from teachers, so the children have appeared to be quite willing to learn. The children are pleased to learn about the basic subjects in the home environment and they have expressed their satisfaction, on the ground that they have not broken away from the educational life. In face-to-face interviews with parents and children, it has been seen that the education has not solely been training; furthermore educational practices have turned into the attitude of therapy.

In this study, regarding their participation in home education, all of the opinions of students and families, who have received home education services, are positive. Child development trainees have also played an active role in the early diagnosis of developmental problems, the content and quality of the report prepared for the child, the content and quality of the support programs designed and implemented, as well as the support for the institution to which the family 
members are to be directed for treatment, support, and education. Child development trainees have also provided an important service to support the development of children by identifying early developmental problems, and by collaborating with children and their families about the developmental problems as early as possible. Holding the children harmless in the service process and using a child-centered and a family-oriented approach, the trainees seem to be quite supportive with developmental programs in terms of directing them to the right centers. Within the scope of the study, positive feedbacks from students and families have revealed the importance of child development experts who have been involved in preventing developmental problems with a child-centered approach, early diagnosis of developmental delays and the support of children with special needs.

Considering these results, the following recommendations can be presented:

It is worthy to integrate the professional trainers, that are specialized in the field provide services, to deal with the children who are getting education at home. The need for qualified staff is also an important aspect of educational services for children with disabilities as reported in PrettiFrontczak \& Bricker (1998). In the Turkish education system, home education services should be expanded and further in-service training should be provided so as to offer a qualified teaching practice. Teachers, who are the main actors of this system, should be supplied with the necessary materials, time and wages. Moreover, it is required to solve the transportation problems of the teachers who come to teach at home; and provide the necessary materials in order to improve the quality of home education. In addition, families should be encouraged to collaborate; and play a more active role in the educational processes of their own children. More advanced technologies of applications such as webbased training should be utilized during home education. The approach that is specifically applied to each child should also be applied to families. The fact that there is a handicapped person in a family forces the people involved in an attempt to survive with a handicap case, which makes all individuals somehow handicapped in a particular circle.

\section{References}

Aymen Peker, E., Taş, E. (2017). Evde Eğitim Uygulaması Üzerine Bir Durum Çalışması: Evde Fen Eğitimi. KSBD, 9 (9): 2, 139-173.

Basham, P., Merrifield, J., Hepburn, C.R (2007). Homeschooling from the Extreme to the Mainstream. Canada: The Fraser Institute. source: on 03.04.2018 from http://www.census.gov/population/www/documentation/ twps0053.html

Bauman, K.J. (2001) Home Schooling in the United States: Trends and Characteristics. Population Division, Working Paper Series No. 53. From online source: http://www.census.gov/population/www/ documentation/twps0053.html\#impact

Collom, E. (2005). The Ins and Outs of Homeschooling: The Determinants of Parental Motivations and Student Achievement." Education and Urban Society, 37, 307-335.

Davies, S., Aurini, J. (2008). Homeschooling and Canadian Educational Politics: Rights, Pluralism and Pedagogical Individualism. Evaluation \& Research in Education 17 (2-3): $63-73$ 
Ensign, J. (2000). Defying the Stereotypes of Special Education: Home School Students. Peabody Journal of Education, 751 (2): 147-158.

Fidan, K. N. (2008). İlköğretimde Araç Gereç Kullanımına İlişkin Öğretmen Görüşleri. Kuramsal Eğitimbilim, 1 (1): 48-61.

Green, C.L., Hoover-Dempsey, K.V. (2007). Why Do Parents Homeschool? A Systematic Examination of Parental Involvement." Education and Urban Society, 39, 264-285.

Hanna, L. (2011). Homeschooling: What's That? Paper presented at the Mid-South Educational Research Association meeting. Education and Urban Society. 44(5), 609-631. $10.1177 / 0013124511404886$

Hill, P.T. (2000). Home Schooling and the Future of Public Education. Peabody Journal of Education. 75 (1/2): 20-31.

Kırcali-Iftar, G. (1998). Özel Eğitim. Özel Gereksinimli Bireyler ve Özel Eğitim. Eskişehir: Anadolu Üniversitesi, Açık Öğretim Yayınları.

Memduhoğlu, H. B., Mazlum, M., Alav, Ö. (2015). Türkiye'de alternatif eğitim uygulamalarına ilişkin öğretmenlerin ve öğretim üyelerinin görüssleri. Eğitim ve Bilim. Cilt 40 (179), 69-87.

Mercan, H., Yildirim Sarı, H. (2018). Lise Öğrencilerinde Akran Zorbalığı ve Sosyodemografik Değişkenlerle İlişkisi. FNJN Florence Nightingale Hemşirelik Dergisi; 26 (1): 21-29.

Ministry of National Education (2010). From online source http://mevzuat.meb.gov.tr/html/2629_0.html on 24.02.2018.

Morton, R. (2010). Home education: Constructions of choice, International Electronic Journal of Elementary Education. 3(1): 45-56.

Patton, M.Q. (2002). Qualitative Research \& Evaluation Methods, 3.rd ed. Thousand Oaks, California: Sage Publications.

Petrie, A.J. (1995). Home Educators and the Law within Europe. International Review of Education. 413 (4): 285-296.

Pretti Frontczak, K., Bricker, D. (1998). An Activity-Based Approach to Early Intervention, London: ETS Publisher.

Roussinov, D., Zhao, J.L. (2003). Automatic discovery of similarity relationships through Web mining. Decision Support Syst., 35(1): 149-166.

Sad, N., Akdă̆, M. (2010). Evde Eğitim. Millî Eğitim Dergisi. Say1 188: 19-31.

Sahin, Y.G., Balta S, Ercan, T. (2010). The Use of internet resources by university students during their course projects elicitation: A Case Study. Turk. Online J. Edu. Technol., TOJET, 9(2): 234-244.

Sezer, G.O (2017). Öğretmenlik Uygulaması Dersini Alan Sınıf Öğretmeni Adaylarının Sınıfta Kullandıkları Materyal Tercihlerinin İncelenmesi. ACJES. Cilt 1, Say1 1, 23-33. $10.31805 /$ acjes.349593

Smith C. F., Williams E. M. (2009). Motivations, Sacrifices, and Challenges: Black Parents' Decisions to Home School. Urban Rev, 41, 369-389.

Spiegler, T. (2009). Why state sanctions fail to deter home education? An analysis of home education in Germany and its implications for home education policies. Theory and Research in Education, 7(3), 297-309.

Taylor, J. C., Therrien, W. J., Kaldenberg, E., Watt, S., Chanlen, N., \& Hand, B. (2011). Using an inquiry-based teaching approach to improve science outcomes for students with disabilities: Snapshot and longitudinal data. Journal of Science Education for Students with Disabilities, 15 (1), 27-39.

Taylor, A. (2012). Self-concept in home schooling children. Ann Arbor, MI: University 
Microfilms International.

Vandenbroeck, M., Roets, G. \& Roose, R. (2012). Why the evidence-based paradigm in early childhood education and care is anything but evident. European Early Childhood Education Research Journal, 20 (4), 537-552

Wayman. K.I., \& Lynch. E.W. (1991). Home-based early childhood services: Cultural sensitivity in a family systems approach. Topics in Early Childhood Special Education. 10 (4). 56-70.

Winstanley, C. (2009). Too cool for school? Gifted children and homeschooling. Theory and Research in Education, 7(3), 347-362.

Yildirim, N., Talas, S., Yazici, L., Nural, H., Celebi, I., Cetin, K., Acet, O., Pelitli, U., Caylak, M. (2015). Evde eğitim alan öğrencilerin eğitim süreçlerinin değerlendirilmesi (Tokat İli Örneği). Eğitim Kuram ve Uygulamaları Araştırmaları Dergisi-EKUAD, 1 (1): 33-52. 